BIOTROPIA No. 12, 1999 : 59 - 77

\title{
THE EFFECTIVENESS OF SOME ECTOMYCORRHIZAL FUNGI IN ALGINATE BEADS IN PROMOTING THE GROWTH OF SEVERAL DIPTEROCARP SEEDLINGS
}

\author{
SUPRIYANTO \\ SEAMEO B1OTROP, P.O Box 116, Bogor 16001, Indonesia
}

\begin{abstract}
The effectiveness of six species of ectomycorrhizal fungi (Scleroderma columnare, S.dictyosporum, Laccaria toccata, Rhizopogon luteolus, Amanita umbronata and Descomyces sp.) in alginate beads in promoting the growth of four species of dipterocarp seedlings (Shorea pinanga, S.leprosula, S.ovalis and Hopea odorata) were studied. Different sodium alginate concentrations of $5 \mathrm{~g}, 10 \mathrm{~g}, 15 \mathrm{~g}$ and $20 \mathrm{~g} / \mathrm{L}$ were tested to find out the best bead's elasticity and spore germination.

Seedling height, Relative Field Mycorrhizal Dependency, percentage of mycorrhizal colonization, nutrient absorption, and the formation of Hartig's net and mantle structure of dipterocarp seedlings were observed 4 months after inoculation.

The best elasticity of alginate beads was found in the concentration of sodium alginate of $15 \mathrm{~g} / \mathrm{L}$. The best growth increment was found in Hopea odorata inoculated with Amanita umbronata (126.60 \%) followed by Shorea pinanga inoculated with Descomyces sp. (27.10\%), Shorea ovalis inoculated with Amanita umbronata (26.90 \%) and Shorea leprosula inoculated with Descomyces sp. (24.20 \%) over the control. The highest Relative Field Mycorrhizal Dependency was found in Hopea odorata followed by Shorea ovalis, S. pinanga and S. leprosula.

The highest mycorrhizal colonization was obtained in Shorea pinanga inoculated with Descomyces sp. (75\%), while inoculation with Amanita umbronata on S.leprosula, S.ovalis and Hopea odorata increased mycorrhizal colonization i.e. $64.5 \%, 52.5 \%$, and $46.2 \%$, respectively.

Hartig's net and mantle structures were well formed in Shorea leprosula as well as S.ovalis seedlings with all mycorrhizal fungi tested, while in S.pinanga seedlings these structures were only well formed with Descomyces sp.

There is no clear difference in P levels in the leaves following inoculation as compared to the controls.

Key words: Mycorrhizas/Alginate beads/Scleroderma columnare/Scleroderma dictyosporumlLaccaria laccatalRhizopogon luteoluslAmanita umbronatalDescomyces sp./Growth/Dipterocarpaceae/Seedlings.
\end{abstract}

\section{INTRODUCTION}

\section{Background}

Industrial Forest Plantation (IFF) is one of the Government Programs to improve the reduced forest productivity due to logging activities (logged-over areas) and deforestation (critical lands). During the period of the Fourth to Sixth Five-year Development Plan of the Government of Indonesia, the area of IFP was projected to be 4.6 million hectares (Departemen Kehutanan 1994). High quality seedlings to replant these areas are needed. Dipterocarp species make up one of the recommended species for sawn-timber production. Dipterocarp is an important timber species in Southeast Asian Countries (PROSEA 1994). Seventy five percent of Indonesian 
wood trading comes from dipterocarp species. Currently, the rate of logging is higher than the rate of replanting. There are some problems in planting dipterocarp species. Among these are the irregular flowering season, recalcitrant seeds, and the need of mycorrhizae for promoting their growth during the seedling stage.

Mycorrhizal research in Indonesia has been promoted by the Government, because of its beneficial contribution to increase the quality of seedlings via growth acceleration (Marx 1973; Supriyanto et al. 1992), to control root pathogenic microorganisms (Marx 1973), to improve soil structure (De la Cruz 1982), to improve rooting system due to hormone production (Gay and Debaud 1987), to increase nutrient and water uptake (Boyle et al. 1987), to increase drought resistance (Boyle et al. 1987; Supriyanto et al. 1992), and to increase the survival rate and accelerate the xylem formation of seedlings obtained by tissue culture techniques (Supriyanto 1989; and Chang 1993).

Inoculum improvements of the potential ectomycorrhizal fungi have been achieved in some species by single spore culture, cell fusion (mating type) and protoplast culture. These techniques can be used for mass production of vegetative inoculum (Fortin et al. 1988).

The inoculum can be packed in several ways such as tablet, capsule, spore powder or mycelium suspension (Supriyanto et al. 1992) and in alginate beads (Supriyanto et al. 1994; Supriyanto 1996). There are some advantages and disadvantages for each type of packaging system. Alginate beads are simple, easily stored, free from climatic influences, inexpensive and are available at any time.

Recent technological improvements of the vegetative inoculum production promote the use of the inoculum packaging system. It is important to evaluate the effectiveness of selected tropical mycorrhizal fungi packed in alginate beads to promote the growth of dipterocarp species recommended for the Industrial Forest Plantation Program.

\section{Objective}

The objective of the research was to compare the effectiveness of alginate inoculum of six species of ectomycorrhizal fungi on the growth of four species of dipterocarp seedlings.

\section{MATERIALS AND METHODS}

\section{Seed Germination}

Dipterocarp seeds (S.pinanga, S.leprosula, S.ovalis, H.odoratd) were collected from Dipterocarp Experimental Areas, Jasinga, Forest Research Institute and were dipped in Dithane M-45 at 1\% concentration for 10 minutes to eliminate the pathogenic fungi. Seeds were germinated in sterilized sand medium. Germination and transplanting media were autoclaved at 1.5 bar, $120^{\circ} \mathrm{C}$ for 30 minutes. Dipterocarp seedlings, two weeks old, were transplanted into poly-bags containing sterilized sand: soil: compost (1:1:1). 


\section{Aiginate Bead Elasticity}

Ectomycorrhizal fungi of Scleroderma columnare, Laccaria laccata, Amanita umbronata, Descomyces sp. were collected from dipterocarp plantation. Scleroderma dictyosporum was collected from Pinus merkusii plantation, while Rhizopogon luteolus was collected from Eucalyptus urophylla plantation.

The spores of ectomycorrhizal fungi were packed in alginate beads based on Le Tacon et al. method (1985) modified by Supriyanto et al. (1994). The elasticity tests of alginate beads were done in different concentrations of sodium alginate $(5,10,15$, $20 \mathrm{~g} / \mathrm{L})$. An amount of $2 \mathrm{~g}$ of ectomycorrhizal fungi spores were extracted from mature fruit bodies and diluted in each different concentration of sodium alginate (an algal extract). Spore suspension was trapped in sodium alginate to form beads in $0.7 \mathrm{M}$ calcium chlorite solution. The alginate bead elasticity was classified into very soft, soft, elastic and hard by pressing the beads in between two fingers. To evaluate the spore viability in different concentrations of sodium alginate, 10 beads were placed in a petri dish containing Modified Melin-Nokran medium. Five replicates were used for the evaluation of each sodium alginate concentration. Germination percentage of the spores in alginate beads was recorded.

\section{Inoculation Technique}

Three-week old dipterocarp seedlings (one week after transplanting) were then inoculated with 5 alginate beads at a concentration of $15 \mathrm{~g} / \mathrm{L}$ sodium alginate. A pipette was used to aspire the alginate beads. The alginate beads were then injected into transplanting media close to the rooting system (at a depth of $2 \mathrm{~cm}$ ). Eight replicates were used for each treatment.

\section{Parameters}

Mycorrhizal seedlings were evaluated 4 months after inoculation on the basis of several parameters to determine the effectiveness of selected mycorrhizal fungi as follows:

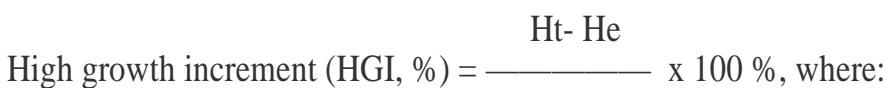

$\mathrm{He}$

$\mathrm{Ht}=$ Height of mycorrhizal seedlings, He = Height of non-mycorrhizal seedlings (control)

Relative Field Mycorrhizal Dependency / RFMD (Plenchette et al. 1983 in Bagyaraj 1994).

$\operatorname{RFMD}(\%)=\frac{\text { DWt-DWc }}{-} \times 100 \%$, where : DWc 
DWt $=$ Dry weight of inoculated seedlings (treatment), DWc : Dry weight of noninoculated seedlings (control)

Seedlings were dried in an oven at $70^{\circ} \mathrm{C}$ for 48 hours and their dry weights were determined. The leaf dry weights were separated for nutrient content analysis.

Percentage of colonization (Fortinef a/. 1982) $=\frac{\text { Number of colonized roots }}{\text { Total number of root samples }} x \mathrm{lOO} \%$

The colonized roots were determined by the presence of hyphae enveloping the roots (external hyphae).

Structural analysis of mycorrhizal and non-mycorrhizal roots was done to observe the presence of Mantle and Hartig's net formation based on the SASS microtechniques method (1958) in Berlyn and Miksche (1976). Toluedine blue 0 of $0.1 \%$ was used for root staining. Toluedine blue 0 stains specifically the mycorrhizal hyphae either mantle or Hartig's net in blue - pinkish color. The presence of Mantle $(\mathrm{M})$, Hartig's Net $(\mathrm{HN})$ or none in the rooting system were used to determine the compatibility of inoculated mycorrhizal fungi and host plant. It was classified into semi-compatible (Mantle only), compatible (Hartig's net and Mantle) or incompatible (no Mantle and no Hartig's net). Good formation of Mantle and Hartig's net will influence the effectiveness of mycorrhizal fungi in nutrient and water absorption. The criteria of mantle formation are as follows: - (negative) for no mantle formation, + (positive) for one layer or poor formation, ++ for two layers or good formation and +$\mathrm{H}$ - for three layers or best formation. The criteria of Hartig's net formation are as follows: - (negative) for no Hartig's-net formation, + (positive) for one series or poor formation, ++ for two series or good formation, +++ for three series or best formation.

Leaf content of N, P, K, Ca, Fe, Mg were used as a nutrient parameter. All of the seedlings were dried at $70{ }^{\circ} \mathrm{C}$ for 48 hours for nutrient analysis. Dried leaves were powdered and $250 \mathrm{mg}$ leaf powder was digested with concentrated $\mathrm{H}_{2} \mathrm{SO}_{4}$ and $30 \%$ $\mathrm{H}_{2} \mathrm{O}_{2}$. The leaf nutrient content was analyzed as follows:

\section{Nitrogen}

Nitrogen content was analyzed using the titration method. To $20 \mathrm{ml}$ of filtered solution in the nitrogen distillate apparatus was added $15 \mathrm{ml}$ of $30 \% \mathrm{NaOH}$. Nitrogen distillation was done for 10 minutes. An amount of $20 \mathrm{ml}$ of $1 \%$ boric acid added to the distillate solution were combined with 3 drops of BCRM (brom cresol green and red methyl) indicator. Titration of the ammonium solution was done using $0.05 \mathrm{~N}$ $\mathrm{H}_{2} \mathrm{SO}_{4}$ 


\section{Phosphate}

Phosphate content was determined spectrophotometrically at $X 693 \mathrm{~nm}$. Phosphate solutions of $0,0.5,1.0,2.0,3.0,4.0,5.0$ ppm were used as standards from which the phosphate content was determined.

\section{Iron}

The wet destruction method of powdered leaf was done using $\mathrm{HNO}_{3}+\mathrm{HC} \mathrm{O}_{4}+$ HjSC^. The iron was analyzed spectrophotometrically at A. $508 \mathrm{~nm}$. An amount of 0.25 $\mathrm{ml}$ of metal reduction solution was added to the destructed solution thoroughly to homogenize the solution. An amount of $0.5 \mathrm{ml}$ of orthophenontroline and $7 \mathrm{ml}$ of sodium citrate were combined. Standardized iron solutions of 0, 1.0, 2.0, 4.0, 6.0 and $8.0 \mathrm{ppm}$ using (NH4)2Fe($\left(\mathrm{SO}_{4}\right) 2$. 6 H2O were used.

\section{Potassium, Calcium and Magnesium}

Atomic absorption spectrophotometry was used to determine the potassium, calcium and magnesium content. Standardized solutions of potassium and calcium each of $0,2.5,5.0,10.0,15.0,20.0$ and 25 ppm were prepared and used to determine potassium and calcium content. To determine magnesium content, standardized solutions of $5 \mathrm{ml}$ magnesium were made from $\mathrm{MgSO}_{4} .7 \mathrm{H}_{2} \mathrm{O}$, i.e. 0, 2.5, $5.0 \mathrm{ppm}$ to which $5 \mathrm{ml} \mathrm{LaCl}$ containing 4000 ppm La were added.

\section{RESULTS}

\section{Alginate Bead Elasticity}

The spore suspension was trapped using sodium alginate and formed to beads in calcium chloride solution. Bead elasticity depended on the concentration of sodium alginate used. The best concentration is determined by the criteria for bead elasticity and germination percentage of trapped spores. This was 15g/L sodium alginate with the average spore germination percentage of $77 \%$ (Table 1 ). The concentration of sodium alginate of $20 \mathrm{~g} / \mathrm{L}$ produced harder beads but the germination percentage of spores trapped in alginate beads decreased. Concentrations of sodium alginate lower than $15 \mathrm{~g} / \mathrm{L}$ produced soft or very soft beads and can easily be dried by airflow even when its spore germination was higher. The concentration of sodium alginate at 15 $\mathrm{g} / \mathrm{L}$ will be used for inoculum packaging system at SEAMEO BIOTROP. This packaging system is easily handled, with high productivity and high inoculum viability. Although Le Tacon et al. (1985) used the sodium alginate at the concentration of $10 \mathrm{~g} / \mathrm{L}$, vegetative mycelia were used instead of spores. 
BIOTROPIA No. 12, 1999

Table 1. Degree of Bead Elasticity and Germination Percentage of Scleroderma columnare Ectomycorrhizal Fungi at Different Concentrations of Sodium Alginate.

\begin{tabular}{|ccccccccc|}
\hline No. & \multicolumn{2}{c}{$5 \mathrm{~g} / \mathrm{LS} . \mathrm{A}}$. & \multicolumn{2}{c}{ lOg/L S.A } & \multicolumn{2}{c|}{$15 \mathrm{~g} / \mathrm{L}$ S.A. } & \multicolumn{2}{c|}{$20 \mathrm{~g} / \mathrm{L}$ S.A. } \\
& $\mathrm{VS}$ & $\% \mathrm{G}$ & $\mathrm{S}$ & $\% \mathrm{G}$ & $\mathrm{ELS}$ & $\% \mathrm{G}$ & $\mathrm{H}$ & $\% \mathrm{G}$ \\
\hline 1 & VS & 70 & $\mathrm{~S}$ & 75 & ELS & 80 & $\mathrm{H}$ & 60 \\
2 & VS & 85 & $\mathrm{~S}$ & 75 & ELS & 75 & $\mathrm{H}$ & 65 \\
3 & VS & 80 & $\mathrm{~S}$ & 80 & ELS & 80 & $\mathrm{H}$ & 60 \\
4 & VS & 758 & $\mathrm{~S}$ & 90 & ELS & 75 & $\mathrm{H}$ & 50 \\
5 & VS & 0 & $\mathrm{~S}$ & 80 & ELS & 75 & $\mathrm{H}$ & 60 \\
\hline Average & VS & 78 & $\mathrm{~S}$ & 80 & ELS & 77 & $\mathrm{H}$ & 59 \\
\hline
\end{tabular}

Note: VS: Very Soft, S: Soft, ELS: Elastic, H: Harder, \% C: Germination Percentage, S.A.: Sodium Alginate.

\section{High Growth Increment (HGI)}

The percentage of high growth increment (HGI) of mycorrhizal seedlings over the control (not inoculated) is presented in Table 2. The best HGI was obtained at Hopea odorata seedlings inoculated with Amanita umbronata (126.60\%). All of the mycorrhizal fungi stimulated the growth of Hopea odorata seedlings, ranging from $40.6 \%$ to $126.60 \%$ and the growth of Shorea pinanga ranging from $5.70 \%$ to $27.10 \%$. The HGI of Shorea pinanga and S. leprosula was promoted by inoculation with Descomyces sp., whereas the HGI of Shorea ovalis and Hopea odorata was promoted best by Amanita umbronata. Scleroderma columnare, Rhizopogon luteolus and Laccaria laccata were not able to stimulate the HGI of Shorea leprosula, and Laccaria laccata was not able to stimulate the HGI of Shorea ovalis. Scleroderma dictyosporum consistently stimulated the HGI of four dipterocarp seedlings tested, ranging from $10.30 \%$ to $75.00 \%$.

Table 2. Percentage of High Growth Increment Over the Control of 4-Month Old Dipterocarp Seedlings Inoculated with Different Species of Ectomycorrhizal Fungi.

\begin{tabular}{|l|c|c|c|c|c|c|}
\hline \multirow{2}{*}{$\begin{array}{c}\text { Dipterocarp } \\
\text { Species }\end{array}$} & \multicolumn{6}{|c|}{ Species of Ectomycorrhizal Fungi } \\
\cline { 2 - 6 } & $\mathrm{Sd}$ & $\mathrm{Sc}$ & $\mathrm{R}$ & $\mathrm{LL}$ & $\mathrm{AM}$ & $\mathrm{DE}$ \\
\hline Shorea pinanga & 10.30 & 5.70 & 12.90 & 13.60 & 15.50 & 27.10 \\
Shorea leprosula & 11.10 & -3.00 & -13.70 & -18.00 & 23.80 & 24.20 \\
Shorea ovalis & 18.30 & 11.60 & 14.10 & -10.80 & 26.90 & 24.10 \\
Hopea odorata & 75.00 & 54.70 & 49.60 & 40.60 & 126.60 & 84.40 \\
\hline
\end{tabular}

Note : Sd: Scleroderma dictyosporum, Sc: Scleroderma columnare, R: Rhizopogon luteolus, LL: Laccaria laccata, AM: Amanita umbronata, DE: Descomyces sp.

The growth response of each dipterocarp seedling inoculated with different mycorrhizal fungi can be seen in Figure 1 (S. pinanga), Figures 4 and 6 (S. leprosula). 

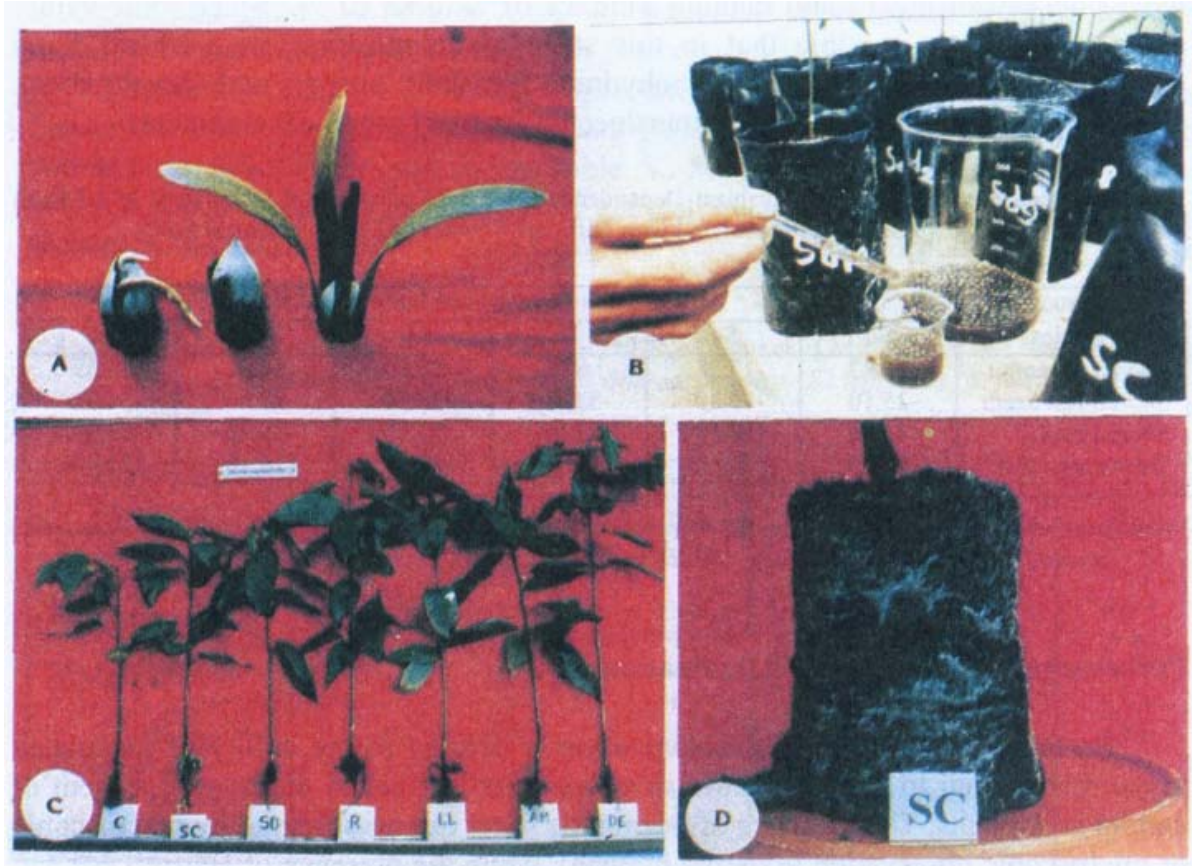

Figure 1: Shorea pinanga seeds (A, x 0.1), alginate beads (B, x 0.18), mycorrhizal seedlings (Sc, Sd, R, LL, AM, DE) and non- mycorrhizal seedlings (c) (C, x 0.06) and the colonization of Scleroderma columnare mycorrhizal fungi at the rooting system of Shorea pinanga seedling (D, $x$ 0.2).

\section{Relative Field Mycorrhizal Dependency (RFMD)}

The influence of mycorrhizal inoculation can also be determined from their Relative Field Mycorrhizal Dependency (RFMD). RFMD is the dependency of a plant species on the mycorrhizal fungi at a given soil fertility. RFMD is determined on the dry weight of mycorrhizal seedlings. It is important because dry weights may reflect the efficiency of physiological processes due to the mycorrhizal inoculation and photosynthetic activity.

Regarding the RFMD value (Table 3), Hopea odorata was very dependent on the inoculated mycorrhizal fungi, ranging from $82.45 \%$ to $416.10 \%$. Shorea pinanga was dependent on Scleroderma dictyosporum (17.87\%), Rhizopogon luteolus (8.6\%), Laccaria laccata (27.82\%), Amanita umbronata (16.82\%) and Descomyces sp. (34.89\%). Shorea leprosula was dependent on Descomyces sp. (34.32\%) and on Amanita umbronata (27.86\%), while Shorea ovalis was dependent on all of 
inoculated mycorrhizal fungi ranging from $32.10 \%$ to $88.20 \%$. Since some values are negative, it is possible that in this stage of colonization, mycorrhizal fungi consumed a high amount of carbohydrate for their energy and development. Generally, those carbohydrates are translocated for plant organ development.

Table 3. Percent Relative Field Mycorrhizal Dependency Over the Controls (not Inoculated) of 4-Month Old Dipterocarp Seedlings Inoculated with Different Species of Ectomycorrhizal Fungi.

\begin{tabular}{|l|c|c|c|c|c|c|}
\hline \multirow{2}{*}{$\begin{array}{c}\text { Dipterocarp } \\
\text { Species }\end{array}$} & \multicolumn{7}{|c|}{ Ectomycorrhizal Fungi } \\
\cline { 2 - 7 } & $\mathrm{Sd}$ & $\mathrm{Sc}$ & $\mathrm{R}$ & $\mathrm{LL}$ & $\mathrm{AM}$ & $\mathrm{DE}$ \\
\hline Shorea pinanga & 17.87 & -12.28 & 8.60 & 27.82 & 16.82 & 34.89 \\
Shorea leprosula & -25.10 & -15.30 & -33.90 & -225.307 & 27.86 & 34.32 \\
Shorea ovalis Hopea & 43.50 & 32.10 & 32.50 & 3.20 & 88.20 & 63.20 \\
odorata & 394.20 & 221.10 & 128.10 & 82.45 & 416.10 & 321.40 \\
\hline
\end{tabular}

Note : Sd : Scleroderma dictyosporum, Sc: Scleroderma columnare, R: Rhizopogon luteolus, LL: Laccaria laccata, AM: Amanita umbronata, DE: Descomyces sp.

\section{Percentage of Mycorrhizal Colonization}

Percentage of mycorrhizal colonization is defined as the ability of inoculated mycorrhizal fungi to form a mantle sheet and Hartig's net in the rooting system of certain host-plants. The presence of the mantle sheet can be observed by macroscopic or microscopic observation (external hyphae), while the presence of Hartig's net can be observed by a microscope (internal hyphae). The presence of mantle and Hartig's net in the rooting system explains the compatibility status between host plant and inoculated mycorrhizal fungi. Technically, the percentage of mycorrhizal colonization is obtained from the hyphal extension that can be observed visually, while the Hartig's net structure must be observed using microscopic magnification.

The extent of mycorrhizal colonization of inoculated mycorrhizal fungi on four species of dipterocarp seedlings is shown in Table 4. The extent of mycorrhizal colonization is classified in five categories: excellent (75 - 100\%), good (50 - 74\%), moderate (24 - 40\%), poor. (1 - 24\%) (Marx and Bryan 1969). Based on this classification, the colonization by Scleroderma dictyosporum, S. columnare, Rhizopogon luteolus, Laccaria laccata, Amanita umbronata and Descomyces sp. are

Table 4. Percentage of Mycorrhizal Colonization in the Root System of 4-Month Old Seedlings of Shorea pinanga, Shorea leprosula, Shorea ovalis and Hopea odorata.

\begin{tabular}{|l|cccccc|}
\hline \multirow{2}{*}{$\begin{array}{c}\text { Dipterocarp } \\
\text { Seedlings }\end{array}$} & \multicolumn{3}{c|}{ Mycorrhizal } & colonization for & \multicolumn{3}{c|}{ each mycorrhizal fungus } \\
\cline { 2 - 7 } & Sd. & Sc. & R & LL & AM & DE \\
\hline Shorea pinanga & 51.87 &, 54.37 & 64.37 & 66.26 & 67.50 & 75.00 \\
Shorea leprosula & 63.00 & 41.50 & 39.00 & 42.50 & 64.50 & 55.50 \\
Shorea ovalis Hopea & 43.10 & 49.40 & 50.00 & 52.70 & 52.5046 .20 & 44.00 \\
odorata & 37.50 & 45.00 & 46.20 & 30.70 & & 37.50 \\
\hline
\end{tabular}

Note : C: Control, Sd : Scleroderma dictyopsorum, Sc: Scleroderma columnare, R: Rhizopogon luteolus, LL: Laccaria laccata, AM: Amanita umbronata, DE: Descomyces sp. 
moderate and good (30.70\% to $75.00 \%$ ). Excellent mycorrhizal colonization was found in Shorea pinanga inoculated with Descomyces sp.

The ability of Scleroderma dictyopsorum, S. columnare, Rhizopogon luteolus, Laccaha laccata, Amanita umbronata and Descomyces sp. to form the Hartig's net and mantle structure is shown in Table 5. Mycorrhizal colonization in Shorea pinanga and $S$. leprosula seedlings were generally classified in term of good and best formation, while S. ovalis and Hopea odorata were classified as poor.

Table 5. The Presence of Mantle and Hartig's net in the Root System of Mycorrhizal and Non-mycorrhizal Seedlings of 4-Month Old Seedlings of Shorea pinanga, S. leprosula, S. ovalis and Hopea odorata.

\begin{tabular}{|c|c|c|c|c|c|c|}
\hline \multirow{2}{*}{$\begin{array}{c}\text { Dipterocarp } \\
\text { Seedlings } \\
\end{array}$} & \multicolumn{6}{|c|}{ Mycorrhizal Fungi } \\
\hline & $\mathrm{Sd}$ & $\mathrm{Sc}$ & $\mathrm{R}$ & $\mathrm{LL}$ & $\overline{\mathrm{AM}}$ & $\overline{\mathrm{DE}}$ \\
\hline Shorea pinanga & & & & & & \\
\hline Mantle & ++ & + &.+++ & ++ & +++ & +++ \\
\hline $\begin{array}{l}\text { Hartig's net } \\
\text { Shorea leprosula }\end{array}$ & ++ & + & + & ++ & $++t$ & ++ \\
\hline Mantle & ++ & ++ & +++ & ++ & +++ & ++ \\
\hline Hartig's net & +++ & +++ & + & - & $++t$ & ++ \\
\hline Shorea ovalis & & & & & & \\
\hline Mantle & + & + & + & + & + & + \\
\hline Hartig's net & + & + & + & + & + & + \\
\hline Hopea odorata & & & & 1 & 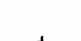 & \\
\hline Mantle & + & + & + & + & + & + \\
\hline Hartig's net & + & + & + & + & + & + \\
\hline
\end{tabular}

Note: - : no formation, + : poor formation, -H-: good formation, +++ : best formation.

C: Control, Sd : Scleroderma dictyosporum, Sc: Scleroderma columnare, R: Rhizopogon luteolus, LL: Laccaria laccata, AM: Amanita umbronata, DE: Descomyces sp.

The extent of mycorrhizal colonization of the inoculated mycorrhizal fungi in dipterocarp seedlings is shown in Figure 2 (S. pinanga), Figures 5 and 6 (S. leprosula), Figure 7a, 7b (S. ovalis). The transversal section showing the mantle and Hartig's net formation in each host plant is shown in Figure 3 (S. pinanga), Figure 8 (S. ovalis).

\section{Leaf Nutrient Content}

Nutrient concentration in the leaves of S.pinanga, S. leprosula, S. ovalis and $H$. odorata is presented in Table 6. Effect of mycorrhizal inoculation on the leaf nutrient content was obtained by comparing the nutrient content of mycorrhizal and non-mycorrhizal seedlings. Table 6 shows that the increment of leaf nutrient content varied depending on the host plant species and the inoculated mycorrhizal fungi. 

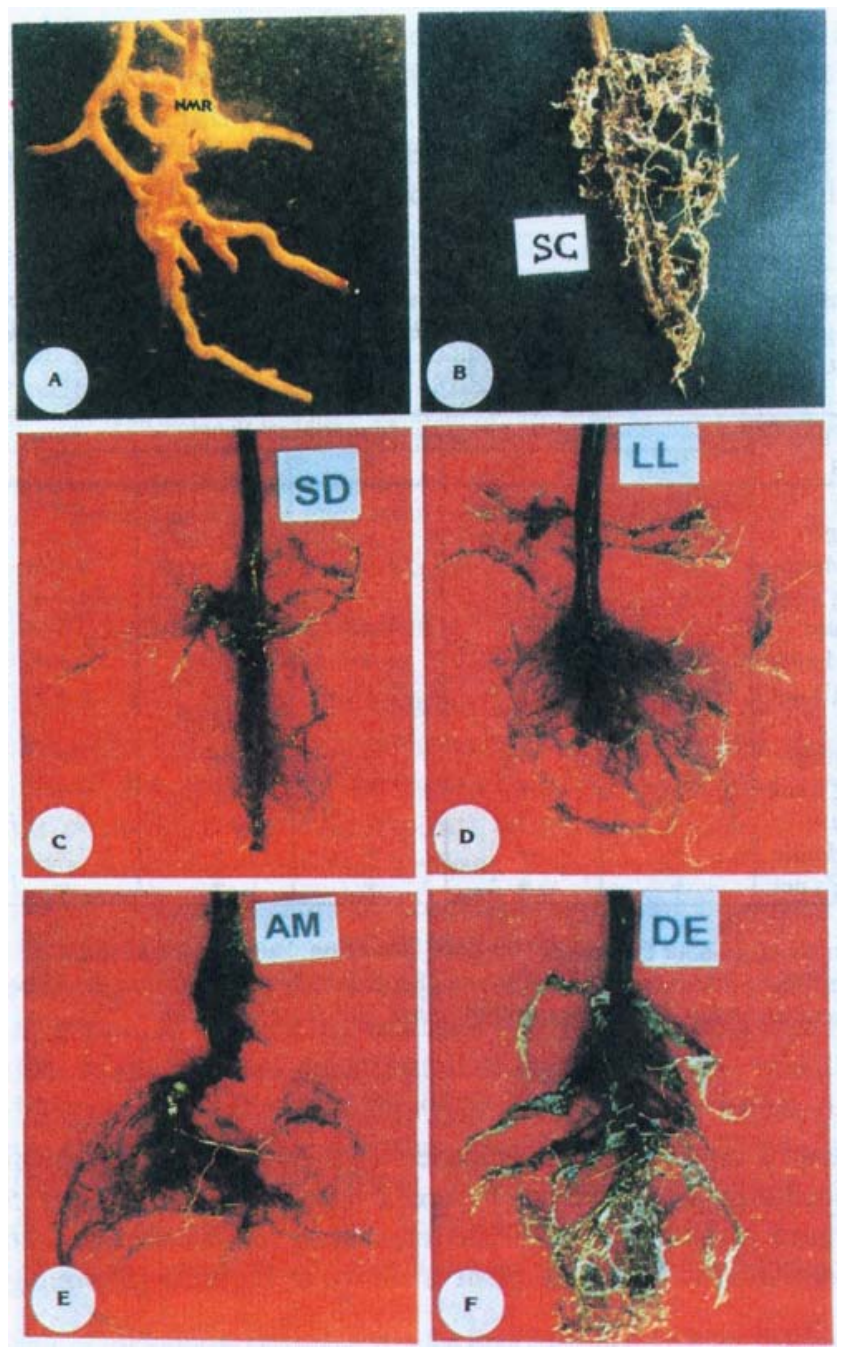

Figure 2: Non-myconhizal and myconhizal root system of Shorea pinanga.

A: Non-mycorrhizal root system (x 10), B: Root system inoculated with S.columnare (x4), C:

Root system inoculated with S.dictyosporum (x 5), D: Root system inoculated with L laccata (x 5),

E: Root system inoculated with A. .umbronata (x 5), F: Root system inoculated with Descomyces sp. (x 5). 
The Effectiveness of some Ectomycornhizal Fungi in Alginate Beads- Supriyanto
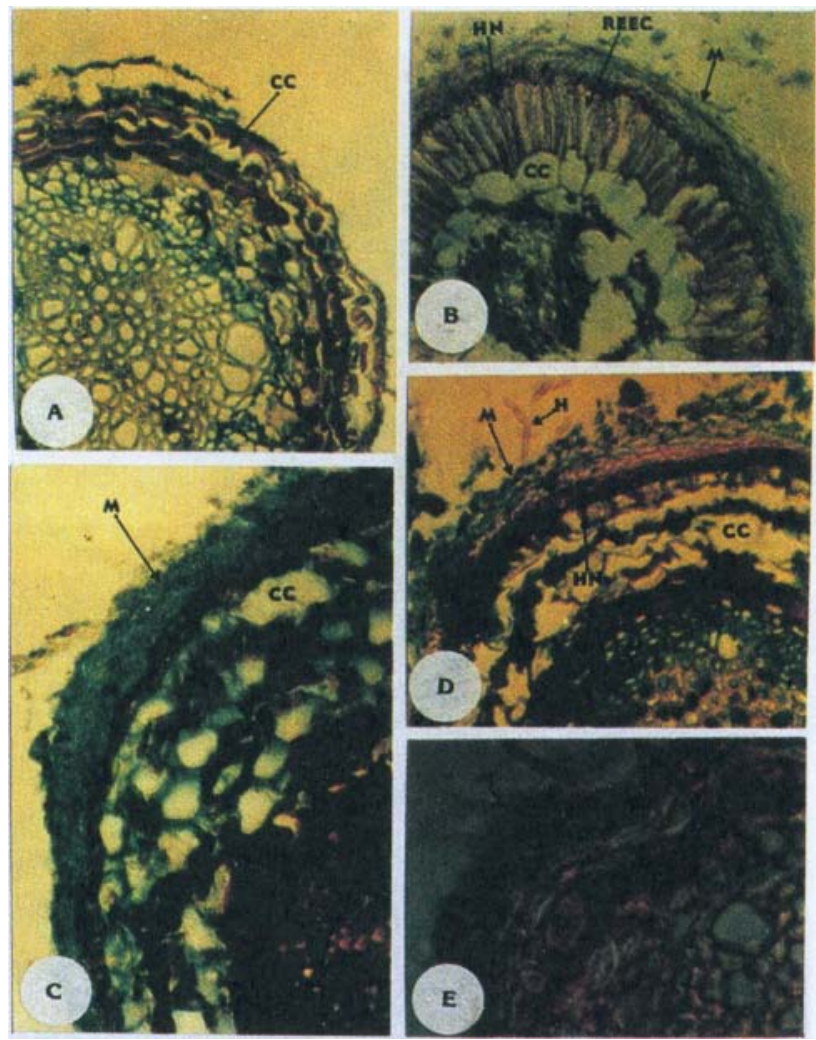

Figure 3 : Transversal section of Shorea pinanga mycorrhizal roots inoculated with S.columnare (B, $\mathrm{x}$ 400), A umbronata (C, x 400), Rhizopogon luteolus (D, x 400), Descomyces sp. (E, x 400) and Non-mycornizal roots (A, x 400). CC = Cortical cells, REEC= Radially elongated epidermis cells, $\mathrm{M}=$ Mantle, $\mathrm{HN}=$ Hartig's net. 

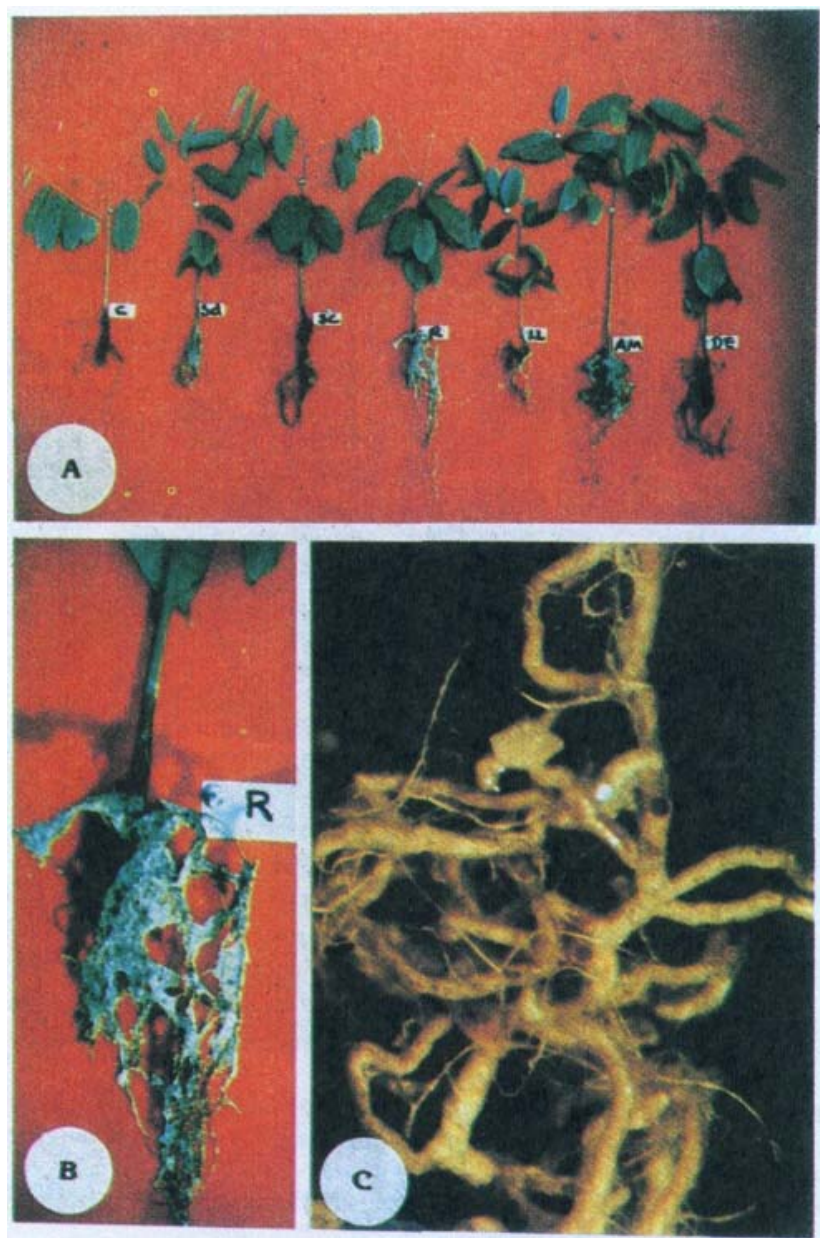

Figure 4 : The growth of non-mycorrhizal seedling (A,c) and mycorrhizal seedlings (Sd: S.dictyosporum, Sc: S.columnare, R: R. luteolus, LL: L.laccata, AM: A.umbronata, DE: Descomyces sp.) of 4month old Shorea leprosula (A, x 0.07) and the colonization of Rhizopogon luteolus (B x 03 C,xl5). 
The Effectiveness of some Ectomycorrhizal Fungi in Alginate Beads - Supriyanto

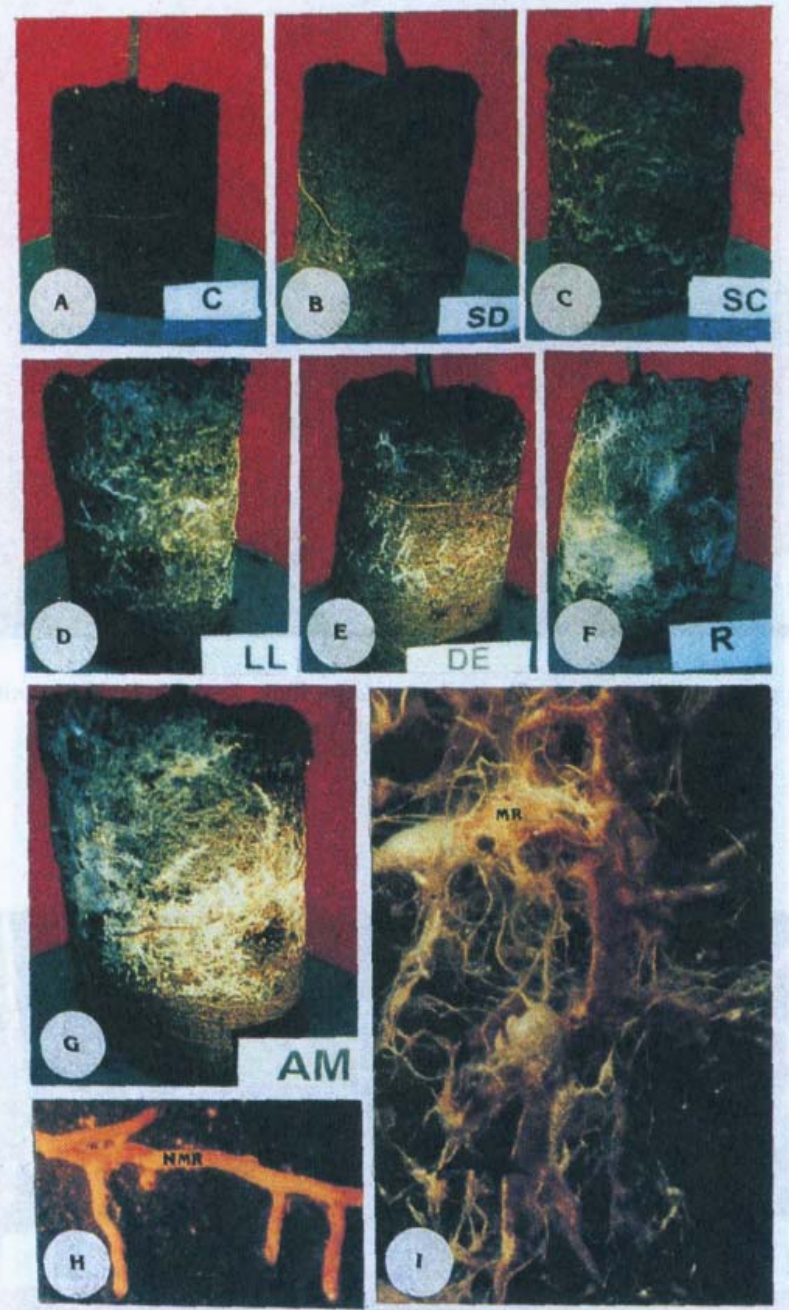

Figure 5 : The development and colonization of mycorrhizal fungi hyphae at the root system of 4-month old Shorea leprosula seedlings.

A (x 0.1) and H (x 10): Non-myconrhizal roots (Control), B: Inoculated with S. dictyosporum (x 0.1 ) and 5". columnare (C, x 0.1), L .laccata (D, x 0.1), Descomyces sp. (E, x 0.1), Rhizopogon luteolus(f,|Q.l),A. umbronata(G,xQ.l;;,x 15). 
BIOTROPIA No. 12, 1999
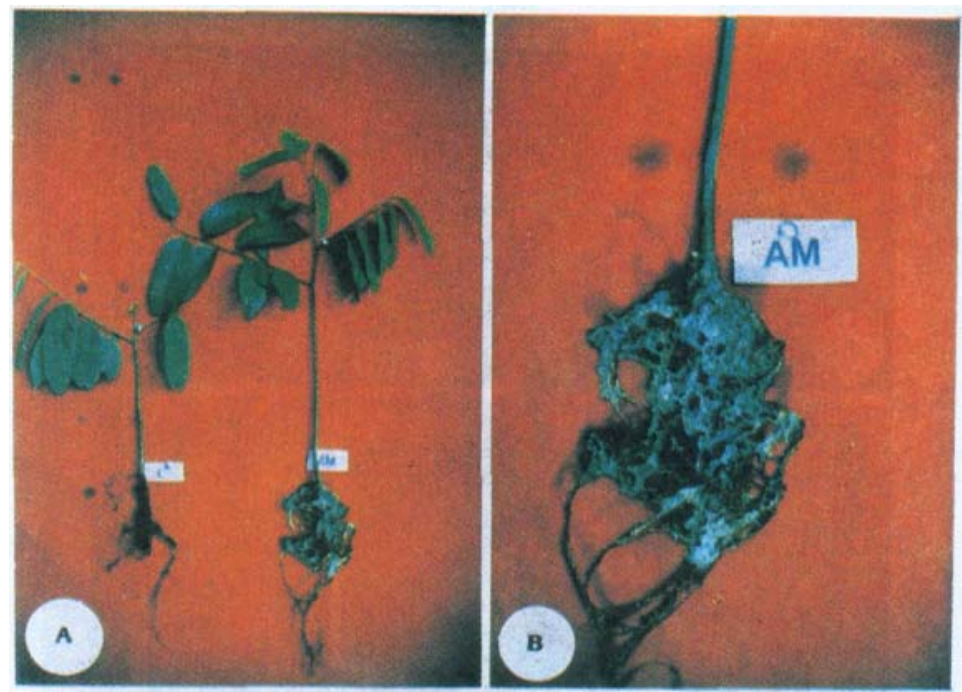

Figure 6: Root system of 4-month old Shorea leprosula seedlings inoculated with Amanita umbronata (A, $\mathrm{x} 0.2, \mathrm{~B}, \mathrm{X} 0.5)$.
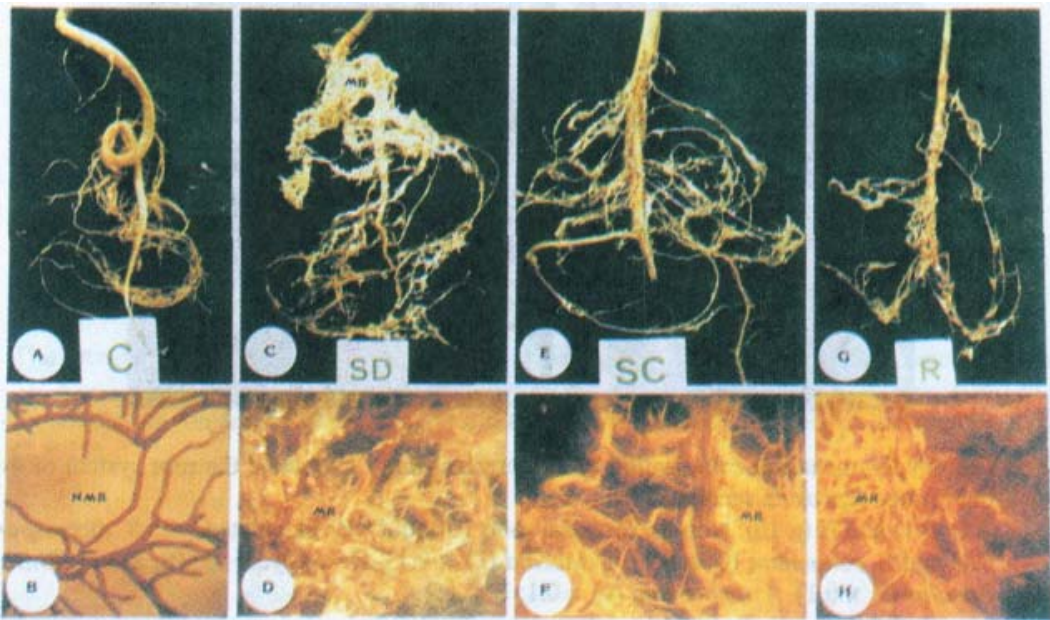

Figure 7a: Degree of mycorrhizal colonization of S.dictyosporum (C, । 0.4; D, x 8), S. columnare (E, x 0.4; F, x 10), Rhizopogon luteolus (G, x 0.4; H, x 10), at root system of 4-month old Shorea ovalis. A, B: non-mycorrhizal roots. 
The Effectiveness of some Ectomycorrhizal Fungi in Alginate Beads - Supriyanto

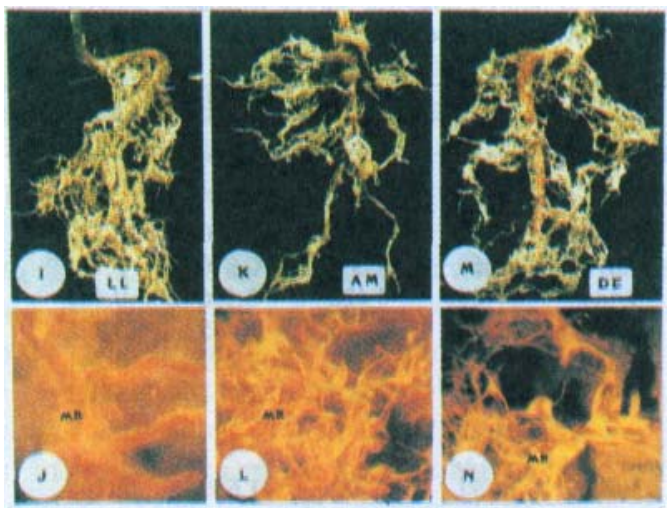

Figure 7b : Degree of mycorrhizal colonization of I.laccata (I, x 0.4; J, x 10), A.umbronata (K, x 0.4; L, x 10), and Descomyces sp. (M, x 0.4; N, x 10).

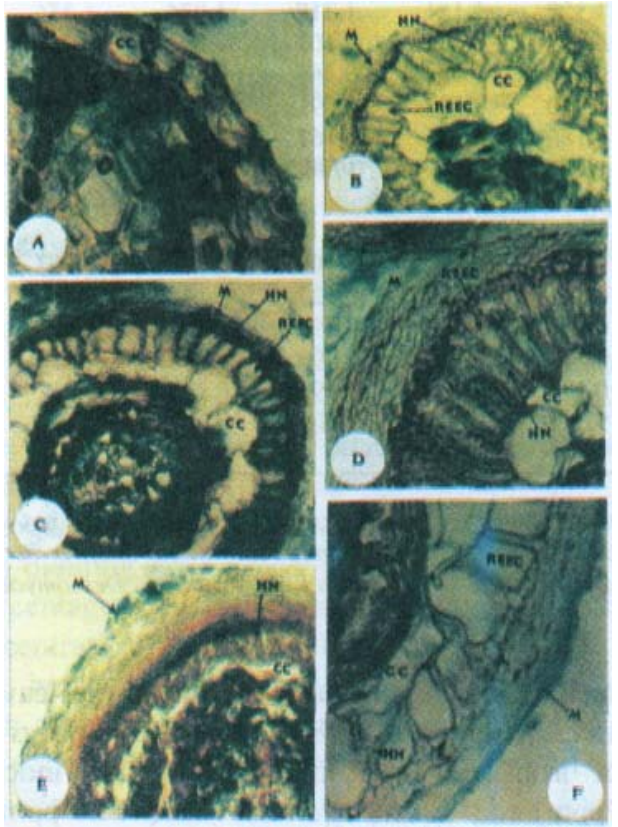

Figure 8 : Transversal section of non-mycorrhizal and mycorrhizal roots of 4-month old Shorea ovalis seedlings.

A. Structure of non-mycorrhizal roots (x 400), and inoculated with S.columnare (B, x 200), 5. dictyosporum (C, x 400), A.umbronata (D, x 400), Descomyces sp. (E, x 400) and Rhizopogon luleolus $(F, x$ 1000). 


\section{BIOTROPIA No. 12, 1999}

Table 6. Leaf nutrient content of Shorea pinanga, Shorea leprosula, Shorea ovalis and Hopea odorata mycornhizal and non-myconhizal seedlings.

\begin{tabular}{|c|c|c|c|c|c|c|c|}
\hline \multirow{2}{*}{$\begin{array}{l}\text { Dipterocarp Species/ } \\
\text { Nutrient }\end{array}$} & \multicolumn{7}{|c|}{ Mycorrhizal Fungi } \\
\hline & $\mathrm{C}$ & Sc & Sd & $\mathrm{LL}$ & $\mathrm{AM}$ & $\mathbf{R}$ & $\mathrm{DE}$ \\
\hline \multicolumn{8}{|l|}{ S. pinanga } \\
\hline $\mathrm{N}(\%)$ & 1.430 & 1.220 & 1.210 & 1.390 & 1.220 & 1.288 & 1.425 \\
\hline $\mathbf{P}(\%)$ & 0.078 & 0.060 & 0.066 & 0.070 & 0.081 & 0.088 & 0.081 \\
\hline$K(\%)$ & 0.438 & 0.427 & 0.428 & 0.406 & 0.487 & 0.465 & 0.449 \\
\hline $\mathrm{Ca}(\%)$ & 0.878 & 0.891 & 0.865 & 1.085 & 0.775 & 0.846 & 1.111 \\
\hline $\mathrm{Mg}(\%)$ & 0.239 & 0.229 & 0.232 & 0.253 & 0.241 & 0.222 & 0.249 \\
\hline $\mathrm{Fe}(\mathrm{ppm})$ & 335.5 & 225.0 & 302.0 & 294.1 & 511.2 & 410.6 & 232.9 \\
\hline \multicolumn{8}{|l|}{ S. leprosula } \\
\hline$N(\%)$ & 1.512 & 1.737 & 1.522 & 1.659 & 1.708 & 1.590 & 1.532 \\
\hline$P(\%)$ & 0.096 & 0.103 & 0.090 & 0.107 & 0.089 & 0.104 & 0.085 \\
\hline$K(\%)$ & 0.508 & 0.535 & 0.513 & 0.529 & 0.535 & 0.513 & 0.529 \\
\hline $\mathrm{Ca}(\%)$ & 0.659 & 0.904 & 0.717 & $0.710^{\circ}$ & 0.607 & 0.601 & 0.736 \\
\hline $\mathrm{Mg}(\%)$ & 0.167 & 0.191 & 0.173 & 0.204 & 0.154 & 0.171 & 0.180 \\
\hline Fé(pînini) & 2566.0 & 1618.5 & 947.4 & 1184.3 & 2033.1 & 1046.1 & 1796.2 \\
\hline \multicolumn{8}{|l|}{ S.ovalis } \\
\hline$N(\%)$ & 1.122 & 1.181 & 1.317 & 1.024 & 1.356 & 1.756 & 1.542 \\
\hline $\mathrm{P}(\%)$ & 0.093 & 0.102 & 0.102 & 0.093 & 0.094 & 0.095 & 0.093 \\
\hline$K(\%)$ & 0.460 & 0.476 & 0.465 & 0.503 & 0.492 & 0.492 & 0.508 \\
\hline $\mathrm{Ca}(\%)$ & 0.710 & 0.594 & 0.691 & 0.723 & 0.840 & 0.613 & 0.723 \\
\hline $\mathrm{Mg}(\%)$ & 0.186 & 0.177 & 0.167 & 0.183 & 0.181 & 0.176 & 0.183 \\
\hline $\mathrm{Fe}(\mathrm{ppm})$ & 1658.0 & 1401.4 & 1796.2 & 1144.8 & 986.9 & 1401.4 & 789.5 \\
\hline \multicolumn{8}{|l|}{ H.odorata } \\
\hline$N(\%)$ & 1.717 & 1.229 & 1.307 & 1.620 & 1.903 & 2.049 & 1.903 \\
\hline$P(\%)$ & 0.143 & 0.180 & 0.127 & 0.147 & 0.151 & 0.135 & 0.140 \\
\hline$K(\%)$ & 0.588 & 0.642 & 0.599 & 0.593 & 0.588 & 0.561 & 0.583 \\
\hline $\mathrm{Ca}(\%)$ & 0.770 & 0.903 & 0.896 & 0.909 & 0.934 & 0.783 & 0.877 \\
\hline $\operatorname{Mg}(\%)$ & 0.170 & 0.196 & 0.194 & 0.207 & 0.201 & 0.181 & 0.200 \\
\hline $\mathrm{Fe}(\mathrm{ppm})$ & 517.1 & 527.0 & 1154.7 & 825.1 & 453.9 & 661.2 & 532.9 \\
\hline
\end{tabular}

Note : Values in bold means nutrient content increment and the values not in bold means no nutrient increment. C: Control, Sc: Scleroderma columnare, Sd.: Scleroderma dictyosporum, R: Rhizopogon luteolus, LL: Laccaria laccata, AM: Amanita umbronata, DE: Descomyces sp.

In S. pinanga seedlings, calcium concentration in the leaves was increased by the inoculation of Laccaria laccata (1.085\%) and Descomyces sp. (1.111\%), while the concentration of iron (Fe) was increased by the inoculation of Amanita umbronata ( $511.2 \mathrm{ppm}$ ) and Rhizopogon luteolus (410.6 ppm). The concentration of $\mathrm{N}, \mathrm{P}, \mathrm{K}$ and $\mathrm{Mg}$ was not significantly influenced by mycorrhizal inoculation.

In Shorea leprosula, the concentration of nitrogen in the leaves was increased by the inoculation of Scleroderma columnare (1.737\%), Laccaria laccata (1.659\%) and Amanita umbronata (1.708\%) and the concentration of calcium and magnesium was increased by the inoculation of Scleroderma columnare (0.904\%) and Laccaria 
laccata (0.204\%). The concentration of P, K and Fe in the leaves was not influenced by the mycorrhizal inoculation.

In Shorea avails, the nitrogen concentration in the leaves was increased by the inoculation of Scleroderma dictyasporum (1.317\%), Amanita umbronata (1.356\%), Rhizopogon luteolus (1.756\%) and Descomyces sp. (1.542\%). The concentration of P, $\mathrm{K}, \mathrm{Ca}, \mathrm{Fe}, \mathrm{Mg}$ in the leaves of Shorea ovalis was not influenced by the inoculation of mycorrhizal fungi.

In Hopea odorata, the nitrogen levels increased with inoculation of Rhizopogon luteolus $(2.049 \%)$ and the level of calcium in the leaves was increased by Scleroderma columnare (0.903\%), Laccaria laccata (0.909\%) and Amanita umbronata (0.934\%). Magnesium level increased with inoculation of Laccaria laccata (0.207\%), Amanita umbronata (0.201\%) and Descomyces sp. (0.200 \%). Iron levels in the leaves of Hopea odorata was increased by the inoculation of Scleroderma dictyosporum (1154.7 ppm), Laccaria laccata (825.1 ppm) and Rhizopogon luteolus (661.2\%).

There is no clear pattern of correlation between inoculation with mycorrhizal fungi and leaf nutrient content. There is also no clear difference in $\mathrm{P}$ concentration in the leaves following inoculation as compared to the controls.

\section{DISCUSSION}

Method of inoculum production of ectomycorrhizal fungi should be easily handled, cheap and effective to increase the seedling quality. Alginate beads, as a carrier of inoculum of ectomycorrhizal fungi, produces an inoculum of high quality and large scale (9,000 - 100,000 beads/hour/machine).

Feldman and Idczak (1994) specified two characteristics of high quality inoculum. High quality means firstly that the inoculum is able to colonize rapidly the plant root system. This is guaranteed by an inoculum of high infection. It does not necessarily mean large number of spores. Secondly, the characteristic of a high quality inoculum is that it should be aseptic or contaminated with only small quantities of plant pathogenic microorganisms. Low level of contamination can be ignored, for example for planting stock production in the nursery.

Regarding the percentage of germination of ectomycorrhizal fungi packed in alginate beads, the concentration of sodium alginate of 5 - $20 \mathrm{~g} / \mathrm{L}$ does not prevent the spore germination, but its elasticity was different. Based on our results, a concentration of sodium alginate of $15 \mathrm{~g} / \mathrm{L}$ was selected because of the high spore germination percentage and good bead elasticity associated with this.

S. columnare, S. dictyosporum, Rhizopogon luteolus, Laccaria laccata, A. umbronata, Descomyces sp. that were packed in alginate beads, were able to colonize the root system of Shorea pinanga, S. leprosula, S. ovalis and Hopea odorata. Their colonization is shown to be moderate to good. The mycorrhizal fungi formed mantle and Hartig's net structures in the root system of the plant. It means that the alginate bead as a carrier of inoculum does not prevent the spore germination. Their degree of 
compatibility can be evaluated on their capability to form the mantle and Hartig's net structure. A mycorrhizal species able to form mantle and Hartig's net structures in several plant species means that this mycorrhizal species has high compatibility. Likely, it is reflected on its natural distribution. Descomyces sp. and A. umbronata were the most possible to form those structures in the root system of dipterocarp species tested. Their degree of compatibility should be followed further on their growth effect and their mycorrhizal dependency value.

Plants differ greatly in their need for, and response to, mycorrhizal infection. Relative Mycorrhizal Dependency (RMD) as degree to which a plant is dependent on the mycorrhizal condition at a given level of soil fertility had been defined (Gerdeman et al. 1975 in Bagyaraj 1994). The RMD concept was also improved to define the mycorrhizal dependency of crops on the mycorrhizal fungi in field conditions, called Relative Field Mycorrhizal Dependency (Plenchette et al. 1983 in Bagyaraj 1994). Based on the first and second rank of RFMD value, the dipterocarp mycorrhizal dependencies are as follows: 5. pinanga to Descomyces sp. and $L$. lacata, $S$. leprosula to Descomyces sp. and A. umbronata, S. ovalis to A. umbronata and $L$. laccata, $H$. odorata to A. umbronata and S. dictyosporum, respectively. Those mycorrhizal fungi are important for improving the growth of dipterocarp seedlings.

Mycorrhizae have long been known to affect the nutrient cycling especially of $\mathrm{P}$ nutrition of the host plant. Phosphate is the major form of $\mathrm{P}$ available in the soil solution and, therefore, it is not readily transported by mass flow. Thus, as mycorrhizal hyphae explore the bulk soil beyond the root hairs, additionally $\mathrm{P}$ is taken up by hyphae and transported to the host (Alien 1996). Mycorrhizal fungi can also increase the uptake of mineralized $\mathrm{P}$ by occupying the microsites of active decomposition 'and, possibly, by being involved in the degradation of litter. Mycorrhizal hyphae on a decomposing leaf and rapid transport of ${ }^{32} \mathrm{P}$ from that leaf to a host plant via mycorrhizal hyphae had been observed (Herrera et al. 1978 in Alien 1996).

By their role in the acquisition of nutrient resources, mycorrhizae are critical components of nutrient cycling. Nutrient levels in the leaves of dipterocarp tested showed that mycorrhizal fungi could increase the nutrient concentration of some of the elements tested in the host plant. Based on our results, there is no clear difference in $P$ levels in leaves following inoculation as compared to the controls.

\section{REFERENCES}

ALlEn, M.F. 1996. The ecology of mycorrhizae, Cambridge Studies in Ecology. Cambridge University Press.

BAGYARAJ, D.J. 1994. Vesicular-arbuscular mycorrhiza: application in agriculture. In J.R. Morris, D. Read and A.K.. Varma (Eds) : Techniques for Mycorrhizal Research, Methods in Microbiology. Academic Press, Harcourt Brace \& Company, Publishers, London-San Diego-New York-BostonSydney-Tokyo-Toronto, p. 819-834.

BERLYN, G.P. and J.P. MIKSCHE, 1976. Botanical microtechniques and cytochemistry. IOWA State University Press, Ames, IOWA. 
BOYLE, C.D., W.J. ROBERTSON and P.O. SALONIUS, 1987. Use of mycelial slurries of mycorrhizal fungi as inoculum for commercial tree seedling nurseries. Can. J. For. Res. 17: 1480-1486.

CHANG, D. 1993. The study of VA mycorrhizal effects on horticultural crops. In Proc. Of Second ACOM, 11-15 March 1991, Chiang Mai, Thailand. Eds. I. Soerianegara and Supriyanto. BIOTROP Special Publication No. 42.

DE LA CRUZ, R.E., 1982. Tree nutrition and fertilization . Lecture note in the Training Course on Biological Aspects of Silviculture, SEAMED BIOTROP, Bogor, Indonesia.

DEPARTEMEN KEHUTANAN, 1994. Rencana Pembangunan Kehutanan PELITA VI. Jakarta, Indonesia.

FELDMANN, F. and E. IDZCEK, 1994. Inoculum production of vesicular-arbuscular mycorhizal fungi use in tropical nurseries. In J.R. Norris, D. Read and A.K. Varma (Eds) : Techniques for Mycorrhizal Research, Methods in Microbiology. Academic Press, Harcourt Brace \& Company, Publishers, ondon-San Diego-New York-Boston-Sydney-Tokyo-Toronto.

FORTIN, C., J.A. FORTIN, G. GAULIN, N. JOMPHE dan S. LEMAY, 1988. Large scale ectomycorrhizal inoculation of containerized grown seedlings. In Proc. of Canadian Workshop on Mycorrhizae in Forestry, 1-4 May 1988.

GAY J.C. and J.C. DEBAUD 1987. Genetic study on indole-3-acetic acid production by ectomycorrhizal Hebeloma species : inter-and intra specific variability in homo and dikaryotic mycelia. Appl. Microbiol. Biotechnol. 26:141-146.

LE TACON, F. , G. JUNG, G. MUNGIER, P. MICHELOT and C.MAPERIN, 1985. Efficiency in a forest nursery of an ectomycorrhizal fungus inoculum, produced in fermentor and entrapped in polymeric gels. Can. J. Bot. 63: 1644-1668.

MARX, D.H. and W.C. BRYAN, 1969. Studies on ectomycorrhizae of pine in an electronical air filtered, air conditioned plant growth room. Can. J. Bot. $47: 1903-1909$.

MARX, D.H. 1973, Mycorrhizae and feeder root diseases. In Ectomycorrhizae : their ecology and physiology. Eds. G.C. Marks and T.T. Kozlowski. Academic Press, New York.

PROSEA, 1994. Plant Resources in South-East Asia 5 : (1) Timber Trees : Major Commercial Timbers. Eds. I.Soerianegara and R.H.M. Lemmens, Prosea Foundation, Bogor, Indonesia - Pudoc-DLO, Wageningen, the Netherlands.

SUPRIYANTO, 1989. Micropropagation de Pinus nigra et Pinus sylvestris', Application a leurs hybrides interspecifiques. PhD Dissertation, University of Nancy I, Nancy, France.

SUPRIYANTO, 1996. Conservation and utilization of mycorrhizal fungi genetic resources. SEAMEO FORUM, Vol. 3 No. 2, SEAMEO - Bangkok.

SUPRIYANTO, I. SETIAWAN dan M. HARAHAP, 1992. Usaha peningkatan kualitas bibit tanaman kehutanan melalui inokulasi mikoriza (pengalaman dan program penelitian SEAMEO BIOTROP). Pros. Seminar Nasional Status Silvikultur di Indonesia Saat Ini. Dept. Kehutanan - APHI - Fak. Kehutanan, UGM. Wanagama, 27-29 April.

SUPRIYANTO, I. SETIAWAN, R.M. OMON, dan E. SANTOSA, 1994. Effects of Scleroderma dictyosporum obtained by protoplast culture on the growth of Shorea selanica and Shorea leprosula cuttings. BIO-REFOR Expert Meeting. JICA-FRIM, Kangar, Malaysia, 28 Nov-1 